\title{
The Effect of Human Development on Mammal Populations of the Punta Leona Private Wildlife Refuge, Costa Rica
}

\author{
Michael Van Hulle ${ }^{1,2}$ \& Christopher Vaughan ${ }^{1,3,4}$ \\ 1. Associated Colleges of the Midwest, Apartado 10265, San Jose, Costa Rica \\ 2. Grinnell College, Grinnell, IA 52803, USA; vanhulle@grinnell.edu \\ 3. Department of Forestry and Wildlife Ecology, University of Wisconsin, Madison, WI 53706, USA; \\ cvaughan@facstaff.wisc.edu \\ 4. International Institute of Wildlife Conservation and Management, Universidad Nacional, Heredia, Costa Rica.
}

Received 03-III-2008. Corrected 10-VII-2008. Accepted 13-VIII-2008.

\begin{abstract}
The effect of human development on six diurnal mammal species was studied using transects in the Punta Leona Private Wildlife Refuge, Puntarenas, Costa Rica during the dry season months of March and April 2006. Individuals $/ \mathrm{km}$ was recorded for each species in more developed (MD) (near paved roads, buildings, construction, or deforested trees) and less developed areas (LD) (secondary forest). The white-faced capuchin monkey (Cebus capucinus) $(\mathrm{n}=233)$, coatimundi (Nasua narica) $(\mathrm{n}=46)$, and Central American spider monkey (Ateles geoffroyi) $(\mathrm{n}=36)$ demonstrated a preference for less-developed habitats. The nine-banded armadillo (Dasypus novemcinctus) $(\mathrm{n}=4)$, tamandua (Tamandua mexicana) $(\mathrm{n}=2)$ and variegated squirrel (Sciurus variegatoides $)(\mathrm{n}=5)$ were observed infrequently. White-faced monkeys avoided construction areas, but received artificial food daily in developed areas. Coatimundis also received artificial foods daily and showed aggression towards guests. Rev. Biol. Trop. 57 (1-2): 441-449. Epub 2009 June 30.
\end{abstract}

Key words: Costa Rica, Cebus capucinus, Nasua narica, Ateles geoffroyi, Dasypus novemcinctus, Tamandua mexicana, Sciurus variegatoides.

Costa Rica is applauded worldwide for its conservation efforts; over $25 \%$ of the national territory is protected wildland areas (Abernathy 1996). This conservation has helped make tourism the country's largest economic industry (Wallace 1996) with over 1,000,000 visitors annually, $58 \%$ of whom come specifically for its natural resources (Wallace 1996, Baker 2004). However, tourism is a double-edged sword in terms of land conservation. It offers an economically sustainable system for land protection (Schutt and Vaughan 1995, Brown 1998, Weaver 2001), yet increases human presence and development (Boo 1990, Weaver 2001). Few quantitative studies have examined the ecological effects of tourism and human development on animals in protected areas in tropical regions. Of the few studies, one found that white-faced capuchin monkeys' (Cebus capucinus) interactions with humans in Manuel Antonio National Park (Costa Rica) caused changes in social and foraging behaviors (Hall 2000).

In 1996, Timmock and Vaughan (2002) conducted a mammal census in Punta Leona Private Wildlife Refuge (PLR), Puntarenas Province, Costa Rica by walking transects in forested areas and counting animals (Table 1). Since then, much of PLR has been developed and some original transect areas are now paved roads with houses and/or construction work in progress. As development continues, it is important to quantify its impact on resident wildlife. Therefore, the objective of this study 
TABLE 1

Population and density estimates from Timmock and Vaughan (2002) (n=10)

\begin{tabular}{lcc}
\multicolumn{1}{c}{ Species } & Density (ind/ha) & Estimated Total Population of Specie in PLR \\
Cebus capucinus & $0.123 \pm 0.07$ & 37 \\
Nasua narica & $0.080 \pm 0.14$ & 24 \\
Sciurus variegatoides & $0.078 \pm 0.10$ & 23 \\
Dasypus novemcinctus & $0.094 \pm 0.12$ & 28 \\
Ateles geoffroyi & $0.036 \pm 0.02$ & 11 \\
Tamandua mexicana & $0.057 \pm 0.04$ & 17
\end{tabular}

was to compare populations of six mammal species in more developed (MD) and less developed (LD) areas of PLR and do a limited comparison to the previous study.

\section{MATERIALS AND METHODS}

Study site: This research was conducted during the dry season months of March and April 2006 in PLR, located north of Jacó, Puntarenas Province, Costa Rica at the mouth of the Gulf of Nicoya ( $\left.84^{\circ} 39^{\prime} \mathrm{W}, 9^{\circ} 41^{\prime} \mathrm{N}\right)$. The land has been privately owned and managed for 35 years by the Punta Leona Hotel and Club. Before their ownership, it was used for agriculture and cattle grazing. The site is around 500 ha with approximately $70 \%$ forest cover (April 22, 2006, personal communication M. Hernandez). It contains secondary wet forests on ridge sides leading into a central valley, secondary dry forests on the highest ridges, and areas of scrub vegetation. As a composite, PLR supports mammal, bird, and reptile populations.

During the 1996 mammal survey (Timmock and Vaughan 2002), human development was concentrated in a central valley containing a hotel and other buildings. Today, the central valley contains more buildings and houses have been constructed on the southern ridge overlooking Playa Blanca and the rock embankments south of the beach. The northern ridge over Playa Limoncito is also currently under construction (Fig. 1).

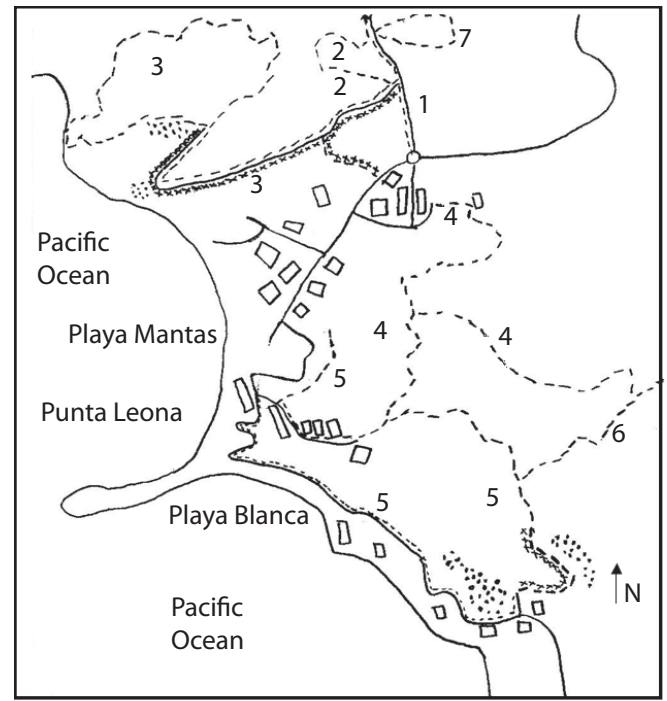

Map Key:

Transect 1: La Entrada

Transect 2: Cristóbal Colón

Transect 3: Limoncito

Transect 4: Selvamar

Transect 5: Playa Blanca

Transect 6: El Mirador

Transect 7: Gigantes

$\longrightarrow$ paved road

- - . - = transect

$\ldots \ldots=$ cleared trees

$\square$ = building

$\operatorname{xxxxx}=$ construction

Study species: The same species censused by Timmock and Vaughan (2002) were examined in the present study: white-faced capuchin monkey, Central American spider monkey 
TABLE 2

Transect lengths and descriptions

\begin{tabular}{|c|c|c|c|c|}
\hline Transect Name & $\begin{array}{l}\text { Less } \\
\text { Developed } \\
\quad(\mathrm{km})\end{array}$ & $\begin{array}{l}\text { More } \\
\text { Developed } \\
\quad(\mathrm{km})\end{array}$ & $\begin{array}{l}\text { Total } \\
(\mathrm{km})\end{array}$ & Description \\
\hline \#1 La Entrada & 0 & 3.16 & 3.16 & $\begin{array}{l}\text { Main paved road leading into the reserve. It began } \\
\text { surrounded by a scrub habitat with cattle grazing on both } \\
\text { sides and a tunnel of bamboo. This was followed by over } 2 \\
\text { km of secondary wet forest on both sides of the road. }\end{array}$ \\
\hline \#2 Cristóbal Colón & .93 & .47 & 1.4 & $\begin{array}{l}\text { Dirt hiking trail to the side of transect \#1 in secondary wet } \\
\text { forest. After } 0.93 \mathrm{~km} \text { it abruptly turned into a paved road } \\
\text { that was nearing completion. }\end{array}$ \\
\hline \#3 Limoncito & 2.98 & 1.13 & 4.11 & $\begin{array}{l}\text { Began on just under } 1 \mathrm{~km} \text { of this same new road and } \\
\text { ascended the northern ridge. The rest was a loop passing } \\
\text { through a recently closed horseback and ATV loop and by } \\
\text { Playa Limoncito. This section contained secondary wet and } \\
\text { dry forests along with a } .4 \mathrm{~km} \text { section of deforested trees, } \\
\text { where four luxury } 8 \text {-story buildings were soon to begin } \\
\text { construction. }\end{array}$ \\
\hline \#4 Selvamar & 2.79 & 0.17 & 2.96 & $\begin{array}{l}\text { Began in an area containing a butterfly farm and gradually } \\
\text { climbed the southern ridge through secondary wet and dry } \\
\text { forests. }\end{array}$ \\
\hline \#5 Playa Blanca & 1.32 & 2.40 & 3.72 & $\begin{array}{l}\text { Originally } 1.61 \mathrm{~km} \text {, it climbed the southern ridge passing } \\
\text { through mostly secondary dry forests and an area of paved } \\
\text { roads and buildings. After three days of surveying, } 2.11 \mathrm{~km} \\
\text { were added that descended the ridge through areas of recent } \\
\text { construction, paved roads, and houses built after Timmock } \\
\text { and Vaughan's (2002) study. }\end{array}$ \\
\hline \#6 El Mirador & .77 & 0 & .77 & $\begin{array}{l}\text { Mix of secondary wet and dry forests on the highest part of } \\
\text { the southern ridge. }\end{array}$ \\
\hline \#7 Gigantes & .83 & 0 & .83 & $\begin{array}{l}\text { A small hiking trail off to the side of transect } \# 1 \text { surrounded } \\
\text { by secondary wet forests. It was added as after three days of } \\
\text { surveying. }\end{array}$ \\
\hline
\end{tabular}

(Ateles geoffroyi), coatimundi (Nasua narica), tamandua (Tamandua mexicana), nine-banded armadillo (Dasypus novemcinctus), and variegated squirrel (Sciurus variegatoides).

Transect lines: A census was conducted using transects passing through secondary wet and dry forests and scrub habitats. Transects were defined in the first two weeks of March. Original transects were used whenever possible, and all transects were paced, converted to km (Table 2), and mapped (Fig. 1). This study's seven transects totaled $17.0 \mathrm{~km}$ whereas the earlier study totaled $17.2 \mathrm{~km}$ (Timmock and Vaughan, 2002).

Unlike the former study (Timmock and Vaughan 2002), this study included transect areas with buildings, construction, and recent deforestation. Transects were divided into MD and LD sections. MD sections were areas with paved roads, buildings, construction, or recently deforested trees. Of the $17.0 \mathrm{~km}$ of trails studied, $7.3 \mathrm{~km}$ were MD and $9.6 \mathrm{~km}$ were LD (Table 2 and Fig. 1). All $17.2 \mathrm{~km}$ of the 1996 study were assumed to be LD as there was no construction in the area at this point.

Transect walking: Data was collected a total of 20 days: a) March 10-22 ( $\mathrm{n}=8$ days) and b) April 3-18 ( $=12)$. Three daily three-hour periods constituted the sampling 
period: 0600-0900, 0900-1200, and 1400-1700. Transects were not walked from 1200 to 1400 hours because of low animal activity due to intense midday heat (Moscow and Vaughan 1987). All seven transects were walked daily, with time periods, starting points, and walking order rotated. Each transect was walked five to eight times for each time period. Three-second pauses were taken every $20 \mathrm{~m}$ to aid observation. Upon visual contact of a mammal, date, time, transect number, species name, number of individuals, habitat, GPS coordinates, perpendicular distance of animal from center of transect, and behavior notes were recorded.

Interviews and other observations: Tourists, contractors, construction workers, restaurant employees, lifeguards, and other staff were informally interviewed about PLR mammals. Any observed interactions between mammals and human development were recorded.

Data analysis: Individuals $/ \mathrm{km}$ for each species was calculated daily in LD and MD habitats. The Kruskal-Wallis ANOVA test was used to determine data significance.

\section{RESULTS}

Animal sightings: In 120 hours of observation and $330.18 \mathrm{~km}$ of transects walked, 322 individual mammals were observed (Table 3 ). Timmock and Vaughan (2002) observed 219 individuals in 77 hours and $172 \mathrm{~km}$ of transects walked. White-faced monkeys were significantly more present than the other species in PLR (Kruskal-Wallis test, $\mathrm{p}=0.003$ ) with 233 individuals observed. Coatimundis and spider monkeys followed with 46 and 36 individuals, respectively. Variegated squirrels $(n=5)$, nine-banded armadillos $(n=4)$, and tamanduas $(\mathrm{n}=2)$ were infrequently observed. Figure 2 compares individuals $/ \mathrm{km}$ in MD and LD areas. White-faced monkeys (Kruskal-Wallis test, $\mathrm{p}=$ 0.003 ), coatimundis (Kruskal-Wallis test, $\mathrm{p}=$ 0.018 ), and nine-banded armadillos (KruskalWallis test, $\mathrm{p}=0.037$ ) were more common in LD areas. Spider monkeys, variegated squirrels, and tamanduas showed no significant difference between MD and LD areas. Figure 3 and Table 3 show individuals $/ \mathrm{km}$ in LD areas between 2006 and 1996. There was little difference in white-faced monkeys and coatimundis but more spider monkeys were observed in 2006. In the 1996 study, four times the number of nine-banded armadillos was seen ( $\mathrm{n}=8$ vs. $\mathrm{n}=4$ ) considering that half the number of days was employed ( $\mathrm{n}=10$ vs. $\mathrm{n}=20$ ) (Timmock and Vaughan 2002). Similarly, Timmock and Vaughan observed 12 variegated squirrels and two tamanduas, while we observed five and two, respectively.

Informal interview and general observation data: Table 4 contains observations and interview data. These include: a) white-faced monkeys and coatimundis are both obtaining artificial food from humans on a daily basis, b) white-faced monkeys avoid construction areas, c) white-faced monkeys sometimes cross paved roads, d) coatimundis can be aggressive towards humans, and e) variegated squirrels, nine-banded armadillos and tamanduas have been observed in MD habitats away from defined transects.

TABLE 3

Individuals $/ \mathrm{km}$ by species in LD and MD areas $(n=20)$ and $1996(n=1)$ with standard deviations shown

\begin{tabular}{lcccccc} 
& $\begin{array}{c}\text { Cebus } \\
\text { capucinus }\end{array}$ & $\begin{array}{c}\text { Nasua } \\
\text { nasua }\end{array}$ & $\begin{array}{c}\text { Ateles } \\
\text { geoffroyi }\end{array}$ & $\begin{array}{c}\text { Tamandua } \\
\text { mexicana }\end{array}$ & $\begin{array}{c}\text { Sciurus } \\
\text { variegatoides }\end{array}$ & $\begin{array}{c}\text { Dasypus } \\
\text { novemcinctus }\end{array}$ \\
\cline { 3 - 6 } Less developed & 0.983 & 0.211 & 0.170 & 0.005 & 0.015 & 0.021 \\
& \pm 0.926 & \pm 0.304 & \pm 0.336 & \pm 0.023 & \pm 0.038 & \pm 0.043 \\
More Developed & 0.314 & 0.041 & 0.027 & 0.009 & 0.014 & 0.0 \\
Timmock (1996a) & \pm 0.539 & \pm 0.090 & \pm 0.071 & \pm 0.043 & \pm 0.042 & \pm 0.0 \\
& 0.860 & 0.267 & 0.023 & 0.011 & 0.070 & 0.047
\end{tabular}



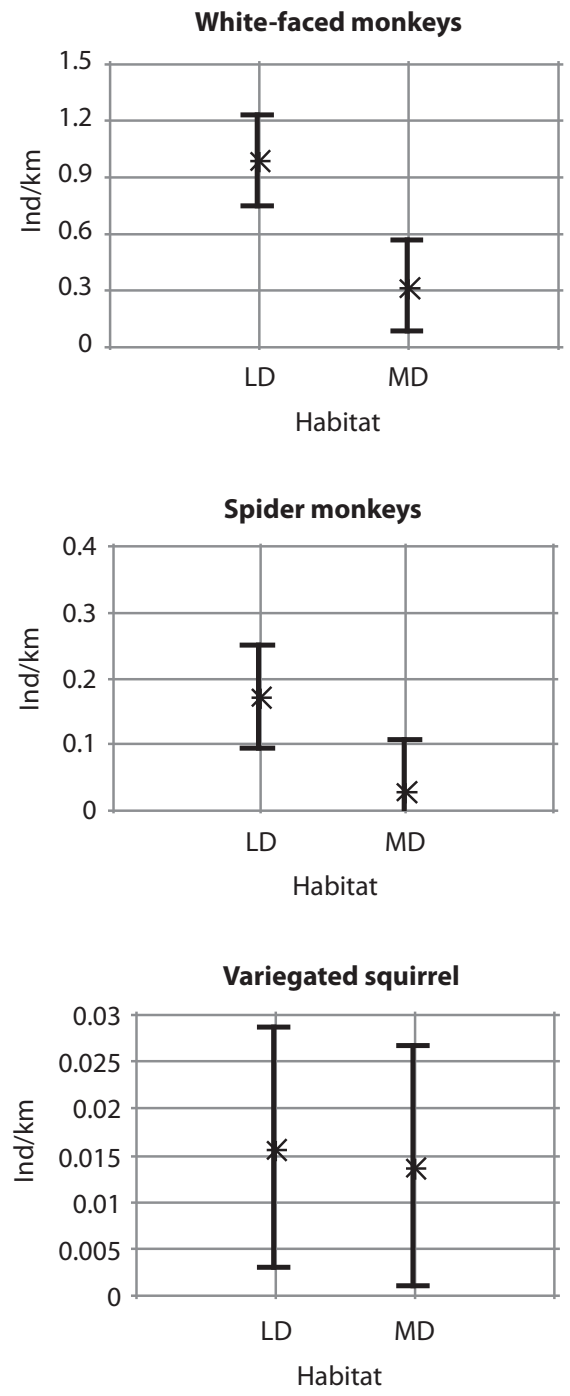
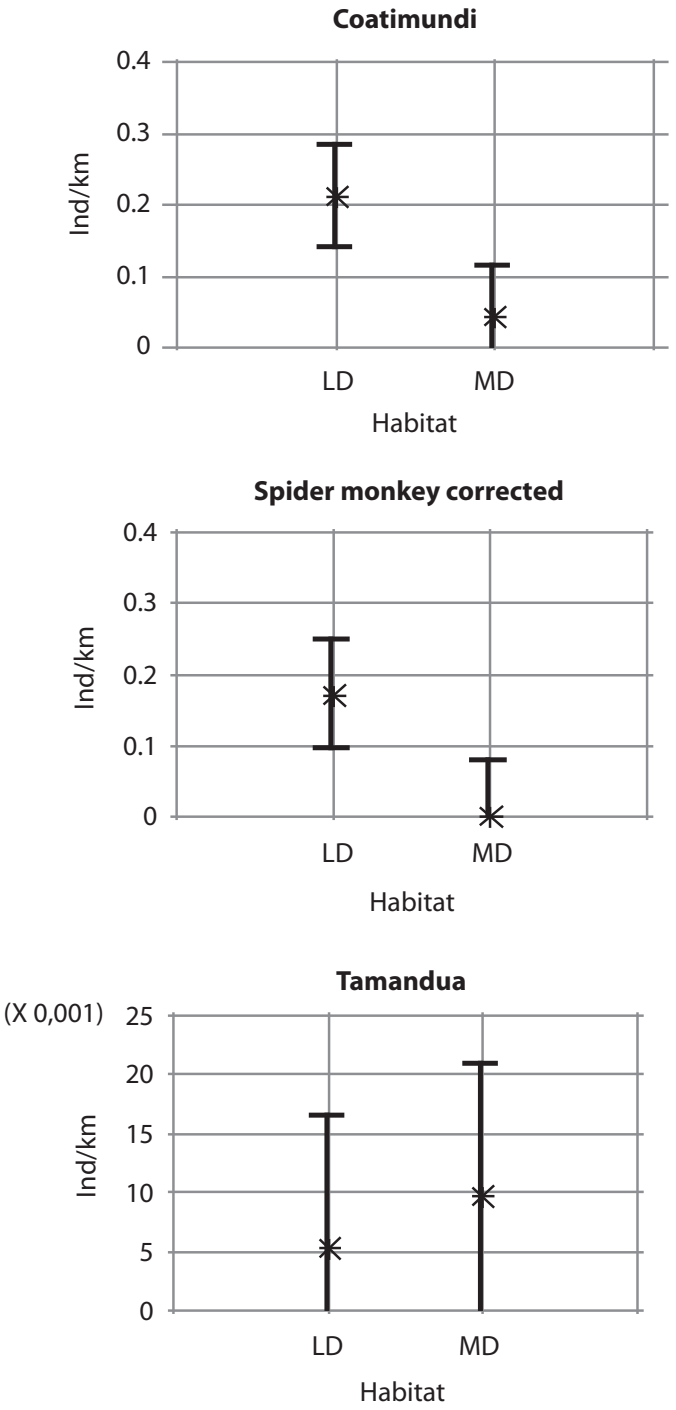

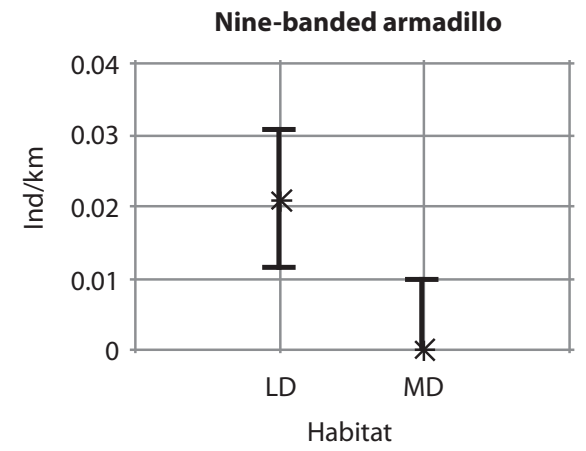

Fig. 2. Mean plots with $95.0 \%$ LSD intervals in LD $(n=20)$ and MD $(n=20)$ areas for each species. 
TABLE 4

Interview and observation data

\begin{tabular}{|c|c|c|c|}
\hline Category & Type of data & Dates & Descriptions \\
\hline \multirow{2}{*}{$\begin{array}{l}\text { White-faced } \\
\text { monkeys } \\
\text { receiving } \\
\text { artificial food }\end{array}$} & $\begin{array}{l}\text { Interview } \\
\text { with restaurant } \\
\text { workers }\end{array}$ & $\begin{array}{l}\text { April } 11 \& \\
12,2006\end{array}$ & $\begin{array}{l}\text { 1. Formerly stealing or being given food by guests daily at } \\
\text { Carabelas restaurant until a construction project began nearby }\end{array}$ \\
\hline & $\begin{array}{l}\text { Interview with } \\
\text { butterfly farm } \\
\text { worker }\end{array}$ & $\begin{array}{l}\text { February } 27, \\
2006\end{array}$ & $\begin{array}{l}\text { 2. One troop arrives daily at 11:00AM to take small fruit items } \\
\text { placed by staff on a pedestal near the butterfly farm }\end{array}$ \\
\hline \multirow{3}{*}{$\begin{array}{l}\text { White-faced } \\
\text { monkeys } \\
\text { avoiding } \\
\text { construction }\end{array}$} & $\begin{array}{l}\text { Interview with } \\
\text { restaurant } \\
\text { workers }\end{array}$ & $\begin{array}{l}\text { April } 11 \& \\
12,2006\end{array}$ & $\begin{array}{l}\text { 1. Formerly stealing or being given food by guests daily at } \\
\text { Carabelas restaurant until a construction project began nearby }\end{array}$ \\
\hline & $\begin{array}{l}\text { Interview with } \\
\text { road construction } \\
\text { workers }\end{array}$ & $\begin{array}{l}\text { April } 7 \& 18 \\
2006\end{array}$ & $\begin{array}{l}\text { 2. Troop daily travels around construction work on transect \#3 } \\
\text { rather than passing through }\end{array}$ \\
\hline & $\begin{array}{l}\text { Observation at } \\
\text { road construction } \\
\text { site }\end{array}$ & $\begin{array}{l}\text { April 12, } \\
2006\end{array}$ & $\begin{array}{l}\text { 3. Viewed traveling around road construction work on transect \#3 } \\
\text { instead of passing through } \\
\text { 4. When road construction workers were not present, they } \\
\text { traveled directly through construction site }\end{array}$ \\
\hline \multirow{3}{*}{$\begin{array}{l}\text { White-faced } \\
\text { monkeys } \\
\text { crossing paved } \\
\text { roads }\end{array}$} & $\begin{array}{l}\text { Interview with } \\
\text { main road guard }\end{array}$ & $\begin{array}{l}\text { March 10, } \\
2006\end{array}$ & $\begin{array}{l}\text { 1. Troop occasionally passes between trees over main entrance } \\
\text { road in front of guard station }\end{array}$ \\
\hline & $\begin{array}{l}\text { Observations on } \\
\text { transect } \# 1\end{array}$ & $\begin{array}{l}\text { March } 18 \text { and } \\
\text { April } 3 \text { and } 4 \\
2006\end{array}$ & $\begin{array}{l}\text { 2. Troop seen three times crossing between trees over main } \\
\text { entrance road }\end{array}$ \\
\hline & $\begin{array}{l}\text { Observation at } \\
\text { road construction } \\
\text { site }\end{array}$ & $\begin{array}{l}\text { April 12, } \\
2006\end{array}$ & $\begin{array}{l}\text { 4. When road construction workers were not present, they } \\
\text { traveled between trees directly over paved road }\end{array}$ \\
\hline \multirow[t]{2}{*}{$\begin{array}{l}\text { Coatimundis } \\
\text { receiving } \\
\text { artificial food }\end{array}$} & $\begin{array}{l}\text { Observations } \\
\text { on beach and } \\
\text { at beachside } \\
\text { restaurant }\end{array}$ & $\begin{array}{l}\text { April } 10,11, \\
\text { and } 17,2006 .\end{array}$ & $\begin{array}{l}\text { 1. Viewed in garbage cans on two separate days } \\
\text { 2. Garbage cans seen tipped over and contents spread out on } \\
\text { beach two separate mornings } \\
\text { 3. Viewed guests feeding them French fries and other food items } \\
\text { on two separate days } \\
\text { 4. Viewed restaurant worker teaching child how to feed coati } \\
\text { 5. Sign informing guests not to feed animals covered by plant }\end{array}$ \\
\hline & $\begin{array}{l}\text { Interview with } \\
\text { restaurant } \\
\text { workers }\end{array}$ & $\begin{array}{l}\text { April 11, } \\
2006\end{array}$ & 6. Come daily to restaurant to receive food \\
\hline $\begin{array}{l}\text { Coatimundis } \\
\text { aggression }\end{array}$ & $\begin{array}{l}\text { Observations } \\
\text { at beachside } \\
\text { restaurant }\end{array}$ & $\begin{array}{l}\text { April 17, } \\
2006\end{array}$ & $\begin{array}{l}\text { 1. Woman attempted to pet coatimundi and coatimundi attempted } \\
\text { to scratch woman }\end{array}$ \\
\hline $\begin{array}{l}\text { Variegated } \\
\text { squirrel in MD } \\
\text { area }\end{array}$ & $\begin{array}{l}\text { Interview with } \\
\text { construction } \\
\text { workers }\end{array}$ & $\begin{array}{l}\text { April } 7 \& 18 \\
2006\end{array}$ & 1. Seen running on telephone line \\
\hline $\begin{array}{l}\text { Tamandua in } \\
\text { MD area }\end{array}$ & Observation & April 5, 2005. & 1. Seen in a tree near buildings \\
\hline $\begin{array}{l}\text { Nine-banded } \\
\text { armadillo in } \\
\text { MD area }\end{array}$ & Observation & $\begin{array}{l}\text { March 8, } \\
2006\end{array}$ & 1. Viewed in sprinklers near pool and in drainage pipes \\
\hline
\end{tabular}




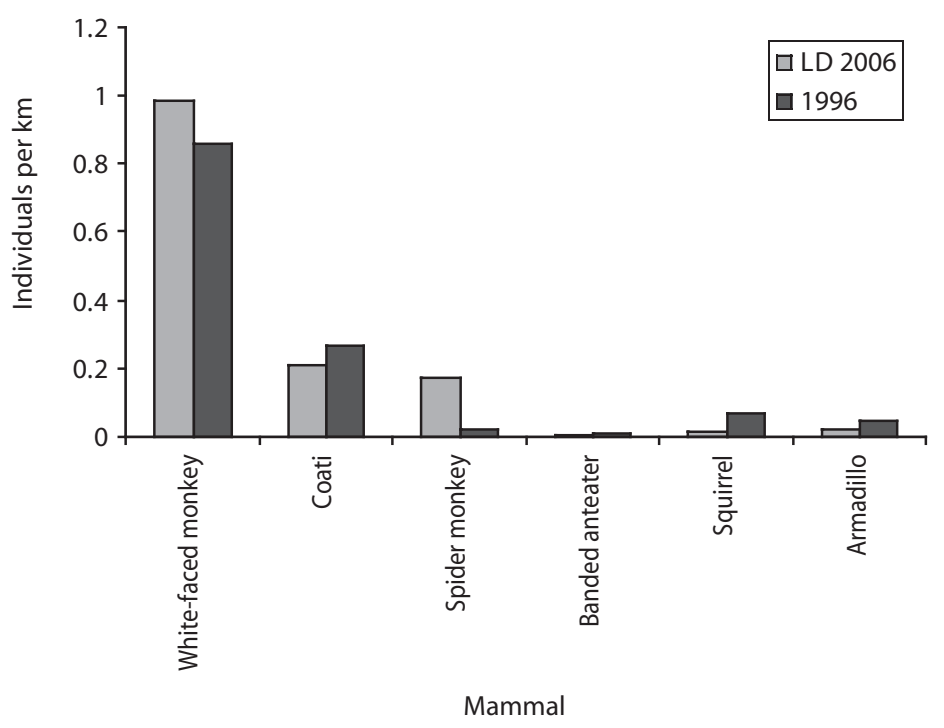

Fig. 3. Individuals/km in $1996(\mathrm{n}=1)$ versus LD areas $(\mathrm{n}=20)$ in 2006.

\section{DISCUSSION}

C. capucinus: Previous research has shown that white-faced monkeys can adapt to many different environments, including those near human development (Fragaszy et al. 2004). However, our research demonstrates that white-faced monkeys in PLR still prefer LD to MD habitats (Fig. 2). Further, we observed instances where white-faced monkeys avoided construction areas (MD) when workers were present (Table 4).

Finally, white-faced monkeys were observed in MD areas for two reasons. First, one troop entered MD areas daily to receive artificial food (Table 4). Although this data does not demonstrate how much receiving human food is affecting them, problems seen in Manuel Antonio, such as smaller home ranges and monkey to human aggression, could occur (Hall 2000). Second, two troops were observed crossing paved roads to inhabit other parts of their home ranges (Table 4). With trees as bridges, roads do not appear to be major barriers.
A. geoffroyi: Considerably more spider monkeys $(\mathrm{n}=36)$ were seen in 2006 compared to 1996 (Timmock and Vaughan 2002) ( $\mathrm{n}=$ 4). This suggests a troop may have established itself in the area since the previous study. This group contains 10-15 individuals and was never seen in MD habitats. The two and only spider monkeys observed in MD areas traveled daily with a white-faced troop observed crossing paved roads. Without these individuals, spider monkeys show a significant preference for LD areas $(p=0.009)$ (Fig. 2).

Although a troop seems to have established itself in PLR, the population density of spider monkeys is still low. Using the estimation of 15 individuals there is a population density of 0.04 ind/ha in PLR, considerably lower than Cant's estimation of 0.28 in Tikal, Guatemala (cited in Timmock and Vaughan 2002). Sorensen and Fedigan (2000) argue that spider monkeys are very susceptible to environmental degradation and have trouble returning to regenerating secondary forests due to their large body 
sizes, specialized diet of fruit and flowers, and large home ranges. Therefore, the low population density in PLR is likely a combination of it being a regenerating secondary forest and environmental degradation caused by human development.

N. narica: Coatimundis in PLR overall prefer LD habitats (Fig. 2). However, at least three individuals frequent Playa Blanca for human food. Observations and interviews (Table 4) indicate that these coatimundis may have developed a daily dependence for artificial food. Aggression could increase if interaction between coatimundis and humans continue (Table 4). Also, because white-faced monkeys eat coatimundi young (Fragaszy et al. 2004), increased competition in white-faced monkeys could possibly lead to higher levels of coatimundi young predation.

S. variegatoides, T. mexicana, and $D$. novemcinctus: Variegated squirrels, tamandua, and nine-banded armadillos were uncommon in this study, perhaps due to their ability to hide and/or the method of transect walking. Further, observations of nine-banded armadillos in MD areas (Table 4) suggest they may actually be abundant in both MD and LD areas.

This study highlighted two important issues for PLR mammals: White-faced monkeys, coatimundis, and spider monkeys prefer LD areas, and PLR should consider these animals' needs while developing new construction projects. In new construction projects, trees serving as bridges must be left so arboreal animals can cross through. Further, large areas of LD environments must be preserved to support spider monkeys, which are susceptible to environmental degradation (Sorensen and Fedigan 2000).

Coatimundis and capuchins are eating artificial food in PLR. Trashcans should be securely covered and rules clearly posted and enforced. Perhaps a pamphlet can be distributed which explains why animals should not be fed or treated like pets. This could prevent potential animal aggression and educate visitors on how to best enjoy nature in PLR.

\section{ACKNOWLEDGMENTS}

Thanks to all of the workers and administrators of the PLR for helping us study within their reserve. Special thanks to Gerardo Avalos and Judith Magnan who helped with statistics and John Guittar for editing multiple drafts. We are also indebted to the Chavez family for feeding, housing, and treating the first author like a member of the family during the fieldwork.

\section{RESUMEN}

Se estudiaron seis especies de mamíferos mediante transectos durante la estación seca tardía (marzo y abril) de 1996 en el Refugio de Vida Silvestre de Punta Leona, Puntarenas, Costa Rica. Se registró la cantidad de animales por $\mathrm{km}$ en lugares con mucho efecto humano (cerca del caminos pavimentados, edificios, construcción, y deforestación) y lugares con menos efecto. El mono carablanca (Cebus capucinus) $(\mathrm{n}=233)$, el pizote (Nasua narica) (n =46), y el mono araña centroamericano (Ateles geoffroyi) $(\mathrm{n}=36)$ prefirieron lugares con menos efecto. Se observó pocos armadillos (Dasypus novemcinctus) $(\mathrm{n}=4)$, osos hormigueros (Tamandua mexicana) $(\mathrm{n}=2)$, y ardillas (Sciurus variegatoides) $(\mathrm{n}=5)$. Los monos carablancas y pizotes aceptan alimentos artificiales y los pizotes fueron agresivos con los turistas. Los carablancas evitan los lugares con construcciones y los caminos pavimentados.

Palabras clave: Costa Rica, Cebus capucinus, Nasua narica, Ateles geoffroyi, Dasypus novemcinctus, Tamandua mexicana, Sciurus variegatoides.

\section{REFERENCES}

Abernathy, G.A. 1996. "The most beautiful beach in the world:" Issues of water quality and tourism in the Quepos/Manuel Antonio Area of Costa Rica, p. 12-20. In J. M. T. Wallace (ed.). Tourism and its consequences: Cases studies from Quepos/Manuel Antonio, Costa Rica, v. 1. North Carolina State University, Raleigh, North Carolina, USA.

Baker, C.P. 2004. Moon handbooks: Costa Rica. Avalon Travel Publishing, Emeryville, California, USA. 
Boo, E. 1990. Ecotourism: The potentials and pitfalls. World Wildlife Fund, Washington, D.C., USA.

Brown, F. 1998. Tourism reassessed: Bright or blessing? Butterworth Heinemann, New York, New York, USA.

Fragaszy, D. M., E. Visalberghi \& L. M. Fedigan. 2004. The complete capuchin: The biology of the genus Cebus. Cambridge University, Cambridge, United Kingdom.

Hall, T. 2000. The effects of tourism on white-faced capuchins (Cebus capucinus) in Manuel Antonio National Park, Puntarenas, Costa Rica. Undergraduate Thesis, Colorado College, Colorado Springs, Colorado, USA.

Moscow, D. \& C. Vaughan. 1987. Troop movement and food habits of white-faced monkeys in a tropical-dry forest. Rev. Biol. Trop. 35: 287-297.

Schutt, A. \& C. Vaughan. 1995. Hacienda Curu: A case in sustainability, p. 147-151. In J. Bissonette \& P.
Krausman (eds.). Integrating people and wildlife for a sustainable future. The Wildlife Society, Washington, D.C., USA.

Sorensen, T. C. \& L. M. Fedigan. 2000. Distribution of three monkey species along a gradient of regenerating tropical dry forest. Biol. Conserv. 92: 227-240.

Timmock, J. \& C. Vaughan. 2002. A census of mammal populations in Punta Leona Private Wildlife Refuge, Costa Rica. Rev. Biol. Trop. 50: 1-12.

Wallace, J. M. T. 1996. Studying tourism in Quepos: Introduction to the research, p. 1-10. In J. M. T. Wallace (Ed.), Tourism and its consequences: Cases studies from Quepos/Manuel Antonio, Costa Rica, v. 1. North Carolina State University, Raleigh, North Carolina, USA.

Weaver, D. 2001. Ecotourism. Wiley; New York, USA. 
